\title{
The Viscous Juncture-Juxta Articular Myxoma
}

\section{Anubha Bajaj*}

Consultant Histopathologist, AB Diagnostics, India

Corresponding to: Anubha Bajaj, Consultant Histopathologist, AB Diagnostics, India; E-mail: anubha.bajaj@gmail.com

Received date: February 6, 2021; Accepted date: February 18, 2021; Published date: February 27, 2021

Citation: Bajaj A (2021) The Viscous Juncture-Juxta Articular Myxoma. Onco Tum Res 2(1): pp. 1-4.

Copyright: (C2021 Bajaj A. This is an open-access article distributed under the terms of the Creative Commons Attribution License, which permits unrestricted use, distribution and reproduction in any medium, provided the original author and source are credited.

\section{ABSTRACT}

Juxta-articular myxoma is an uncommon, benign, hypocellular, bland, myxoid neoplasm of mesenchymal origin occurring within the vicinity of a large joint such as the knee. The neoplasm is exemplified within 16 years to 83 years with a median age of 43 years. A male predominance is observed with a male to a female proportion of nearly 3:1. Localized tissue destruction arising on account of the neoplasm can engender pain or nerve palsy. The minimally cellular tumefaction depicts an abundant, myxoid stroma admixed with a non-malignant proliferation of spindle-shaped cells. Juxta-articular myxoma is immune reactive to vimentin and CD34.

\section{Keywords:}

Juxta-articular, Myxoma, Malignant, Lymphocytes.

\section{Introduction}

Juxta-articular myxoma is an uncommon, benign, hypocellular, hypo-vascular, bland, myxoid neoplasm of mesenchymal origin emerging within the vicinity of a large joint. The frequently cystic neoplasm simulates a ganglion and is predisposed to localized tumour reoccurrence following inadequate surgical eradication. Segregation of the locally destructive, painful juxta-articular myxoma from a myosarcoma can be challenging. Of obscure pathogenesis, myxoma was initially described as a neoplasm by Virchow in 1863 [1].

Disease Characteristics Juxta-articular myxoma is commonly associated with large joints such as the knee which is incriminated in a majority (88\%) of instances. Additionally, elbow, shoulder, ankle, wrist, hip or joints of the hand may be implicated $[2,3]$. Tumour magnitude generally varies from 0.6 centimetres to 12 centimetres although a majority of neoplasms are beneath $<5$ centimetres.

The neoplasm is frequently associated with conditions such as meniscal tear and osteoarthritis(2,3). Disease emergence usually occurs within the third to fifth decades. The neoplasm is exemplified within 16 years to 83 years with a median age at 43 years. Children are exceptionally incriminated wherein the neoplasm is usually discerned within the knee joint or wrist. A male predominance is observed with a male to the female proportion of nearly $3: 1[2,3]$. Although the tumefaction is non-destructive or locally destructive, an estimated one third (34\%) of neoplasms are associated with localized tumour reoccurrence. Of controversial genesis, juxta-articular myxoma may be engendered as a posttraumatic consequence or an arthritic disease [2,3]. Clinical Elucidation Pain can occur in the absence of clinically evident neoplasm although tumefaction can arise in the absence of pain. On account of localized tissue destruction associated with the neoplasm, pain or nerve palsy can manifest $[2,3]$. The occurrence of a painful lesion requires differentiation from localized or referred hip pain arising due to concomitant disorders of knee or foot. Nevertheless, a nonrepresentative medical history of inflammatory disease and traumatic disorders is encountered. Additionally, incriminated subjects can be asymptomatic $[3,4]$.

Tumours implicating the metatarsophalangeal are gradually progressive and appear as a solid, circumscribed, spherical nodule of varying magnitude with adherence to abutting joints although coherence to adjacent tendons or cutaneous surfaces is absent $[3,4]$. Histological Elucidation Grossly, the myxoid or mucoid neoplasm is cystic, slimy, friable, well-circumscribed, pale, whitish to yellow and up to 6 centimetres magnitude. The cut surface of the encapsulated tumour depicts a mucoid, multinodular appearance $[3,4]$. On microscopy, the neoplasm is traversed by strands of fibrous tissue with enmeshed, scattered chronic inflammatory cells such as lymphocytes and histiocytes. An infiltrative, hypocellular and hypo-vascular tumefaction composed of miniature, stellate or spindle-shaped cells admixed within an abundant myxoid matrix is observed $[3,4]$.

The neoplasm consists of thick-walled, cystic articulations with the dissemination of miniature, elliptical to spindle-shaped and fibroblast-like cells embedded within an abundantly myxoid stroma. Cytological atypia is absent $[3,4]$. Characteristically, tumefaction is minimally cellular and depicts an abundant, myxoid stroma with intralesional vascularization. Aberrant accumulation of mucinous stroma is admixed with aggregates of mesenchymal cells. A non-malignant proliferation of spindleshaped cells is encompassed within a myxoid matrix $[3,4]$.

Minimal quantities of spindle-shaped, fibroblast-like, stellate or fusiform cells are entangled within a network of reticulin fibres, myxoid matrix and inadequately configured vascular articulations. Stromal mucin is constituted by hyaluronic acid and mucopolysaccharides. Loosely configured, spindle-shaped cells are enveloped within a hypovascular, myxoid matrix with scattered, variable cystic articulations $[3,4]$. Zones of cellular and nuclear atypia, pleomorphism, mitotic activity or tumour necrosis are absent. Focal accumulates of inflammatory exudate, vascular configurations or haemorrhage are delineated. Foci of enhanced cellularity may be denominated $[4,5]$.

\section{Immune Histochemical Elucidation}

Juxta-articular myxoma is immune reactive to vimentin, CD34 and exceptionally to Smooth Muscle Actin (SMA). Muciphages are immune reactive to $\mathrm{CD68}$. The neoplasm is immune non- 


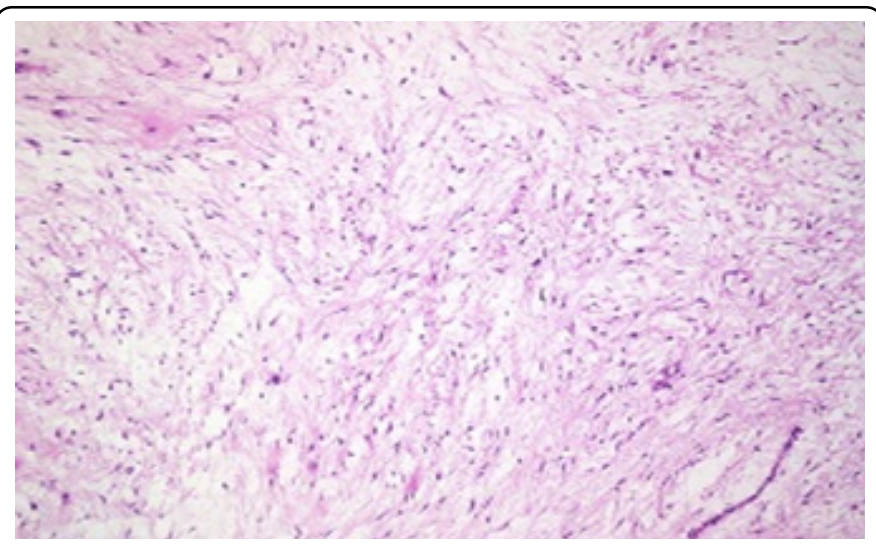

Figure 1: Juxta-articular myxoma comprised of minimalistic, spindle-shaped fibroblastic cells and an enveloping myxoid matrix.

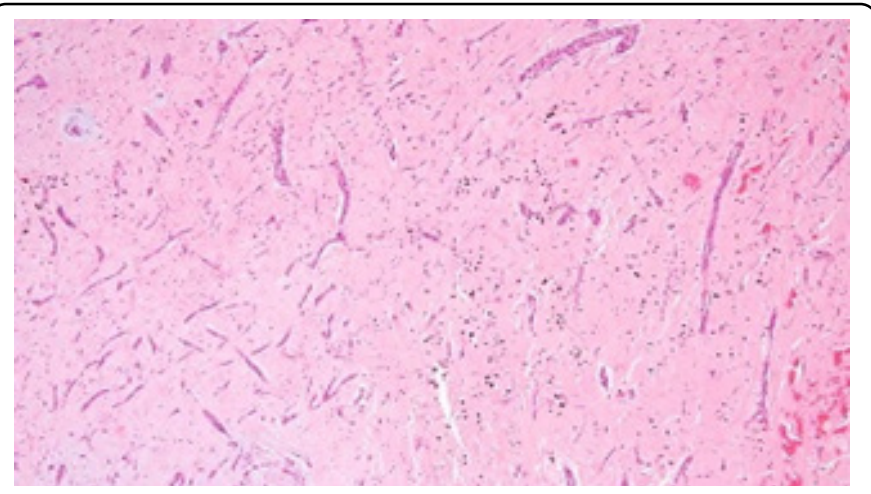

Figure 2: Juxta-articular myxoma delineating a paucity of spindle-shaped, fibroblastic cells commingled within a predominantly myxoid stroma.

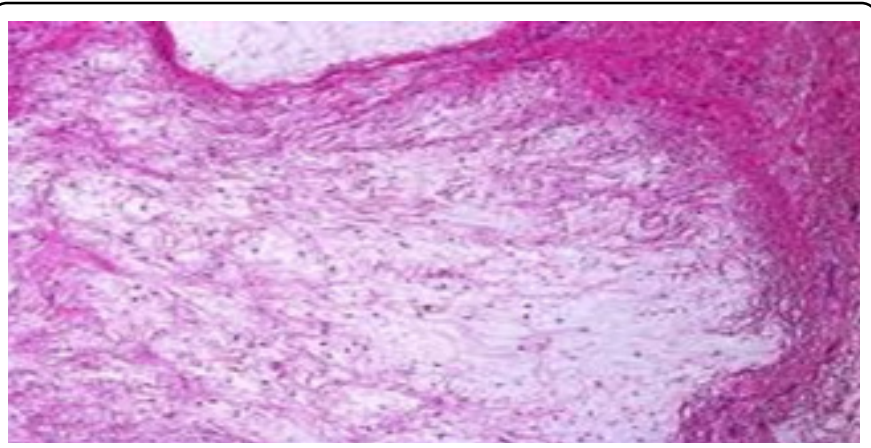

Figure 3: Juxta-articular myxoma depicting an abundant myxoid matrix and an intermingling of spindle-shaped, fibroblastic cells.

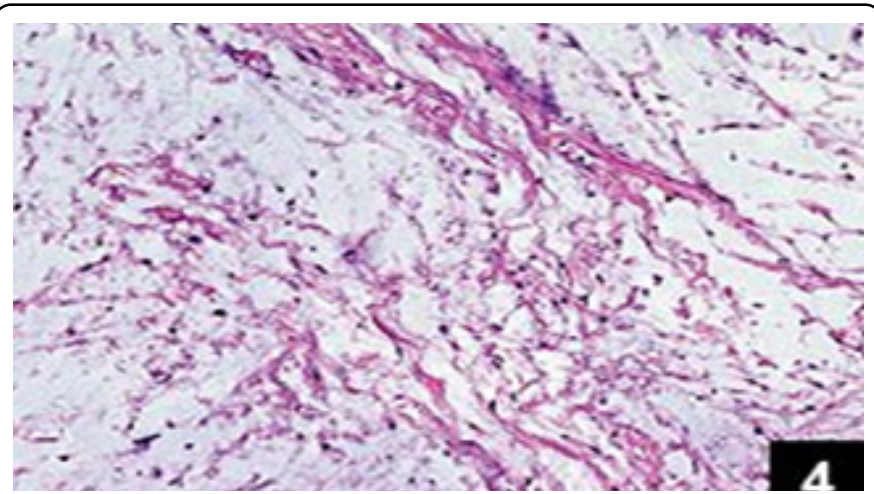

Figure 4: Juxta-articular myxoma delineating spindle-shaped, fibroblastic cells disseminated within a copious myxoid matrix.

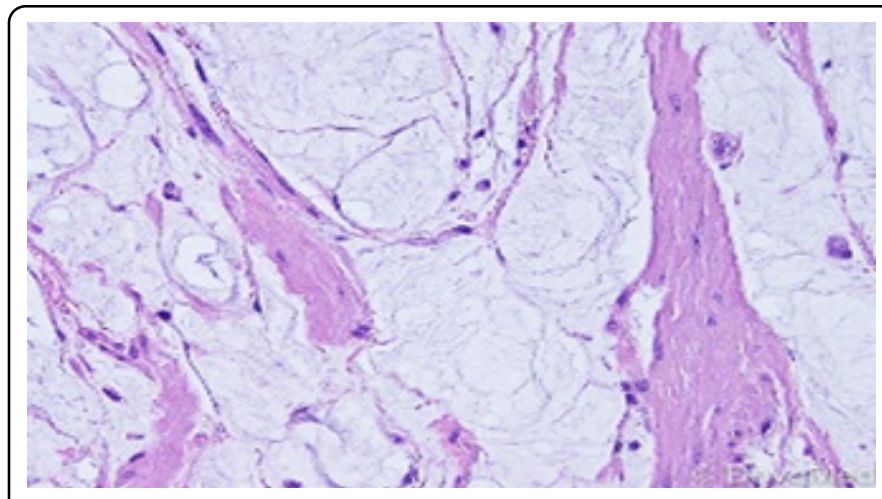

Figure 5: Juxta-articular myxoma comprised of an abundance of myxoid stroma and intermingled spindle-shaped fibroblastic cells.

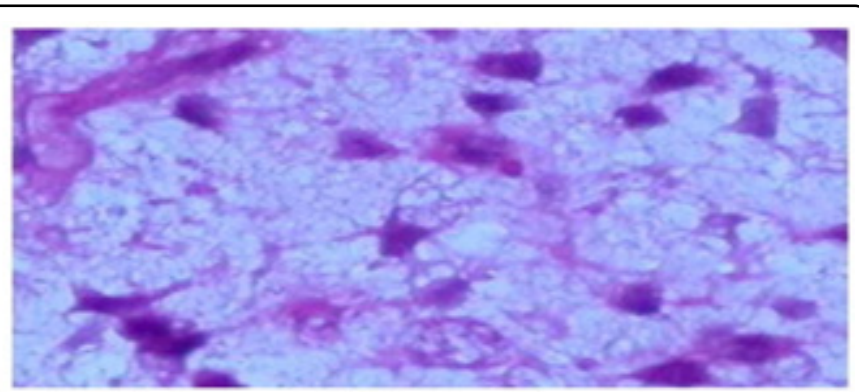

Figure 6: Juxta-articular myxoma composed of minimal spindle-shaped, fibroblastic cells admixed within an abundant myxoid stroma.

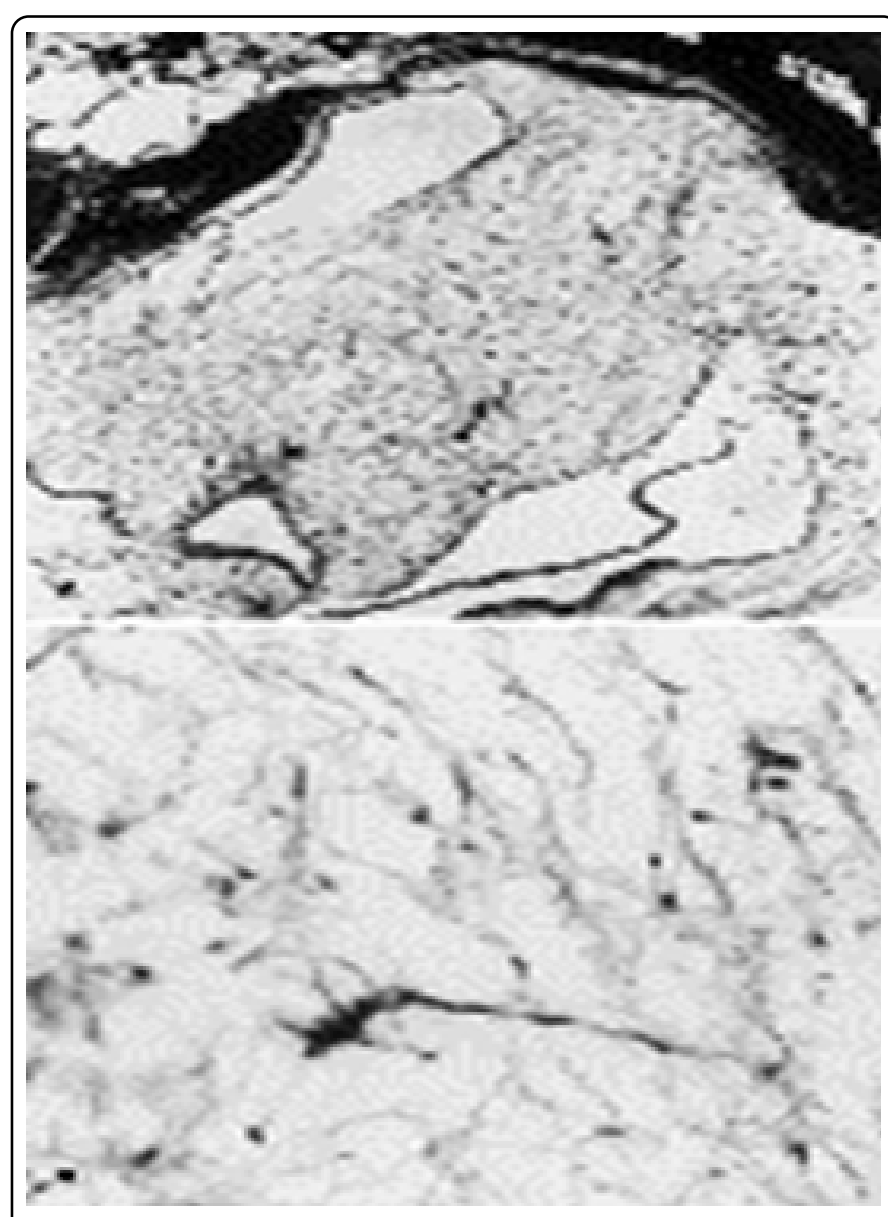

Figure 4: Juxta-articular myxoma depicting abundant myxoid matrix admixed with few spindle-shaped cells and minimal capillaries. 
reactive to desmin, actin or S100 protein $[2,3]$.

\section{Differential Diagnosis}

The distinction of juxta-articular myxoma is necessitated from associated benign and malignant neoplasms such as intramuscular myxoma which is an intramuscular, homogenous, extensively pauci-cellular, minimally fibroblastic neoplasm with few cystic structures. The neoplasm denominates a female predominance, usually appears around 50 years and incriminates large muscle of thigh or shoulder. Localized tumour reoccurrence is minimal, despite inadequate surgical resection. Tumefaction demonstrates an activating missense Gs alpha mutation at Arg201 codon with consequently enhanced levels of cyclic adenosine monophosphate. Ultrasonography and MRI depicts an elevated intrinsic water content with the peripheral rim of adipose tissue $[5,6]$.

Table 1: Differential Diagnosis of Juxta-articular Myxoma

\begin{tabular}{|c|c|c|c|c|}
\hline Tumefaction & Site & Clinical Features & Morphology & Prognosis \\
\hline $\begin{array}{l}\text { Intramuscular } \\
\text { myxoma }\end{array}$ & $\begin{array}{l}\text { Large muscles of thigh, } \\
\text { shoulder, buttock and } \\
\text { upper arm }\end{array}$ & $\begin{array}{l}\text { Gradually evolving, } \\
\text { painless mass. Adults. } \\
\text { Females>males }\end{array}$ & $\begin{array}{l}\text { Interstitial mucin, sparse } \\
\text { stromal spindle cells, strands } \\
\text { or trabeculae of fibrous } \\
\text { tissue }\end{array}$ & $\begin{array}{l}\text { Infrequent localized } \\
\text { recurrence, absent } \\
\text { possible metastasis }\end{array}$ \\
\hline Myxofibrosarcoma & $\begin{array}{l}\text { Subcutis, unrelated to } \\
\text { joints, trunk, pelvis, } \\
\text { genitalia, head and } \\
\text { neck }\end{array}$ & $\begin{array}{l}\text { Painless, gradually } \\
\text { evolving singular } \\
\text { nodule of } 10 \mathrm{~cm} \\
\text { magnitude Adults }\end{array}$ & $\begin{array}{l}\text { Cellular atypia, variable } \\
\text { proportion of cellular and } \\
\text { myxoid areas }\end{array}$ & $\begin{array}{l}\text { Aggressive, enhanced } \\
\text { localized recurrence } \\
\text { and notable metastasis }\end{array}$ \\
\hline $\begin{array}{l}\text { Low-grade } \\
\text { fibromyxoid sarcoma }\end{array}$ & $\begin{array}{l}\text { Muscles of lower limb, } \\
\text { pelvic girdle, (rare) } \\
\text { upper limb, shoulder } \\
\text { girdle }\end{array}$ & $\begin{array}{l}\text { Indolent clinical } \\
\text { course. Young adults } \\
\text { and children }\end{array}$ & $\begin{array}{l}\text { Alternating dense fibrous } \\
\text { tissue, hypocellular myxoid } \\
\text { nodules and cellular areas } \\
\text { around small blood vessels }\end{array}$ & $\begin{array}{l}\text { Substantial localized } \\
\text { recurrence and } \\
\text { metastasis }\end{array}$ \\
\hline Myxoid liposarcoma & $\begin{array}{l}\text { Lower limb, } \\
\text { retroperitoneum (rare) }\end{array}$ & $\begin{array}{l}\text { Gradually evolving, } \\
\text { painless mass }>10 \mathrm{~cm} \\
\text { at presentation Young } \\
\text { adults }\end{array}$ & $\begin{array}{l}\text { Low grade, hypocellular, } \\
\text { bland, spindle cell } \\
\text { proliferation in an abundant } \\
\text { myxoid background, thin } \\
\text { walled, capillary sized, } \\
\text { plexiform vascular network. } \\
\text { High grade hypercellular } \\
\text { regions }>5 \% \text { of tumour }\end{array}$ & $\begin{array}{l}\text { Low grade metastatic } \\
\text { risk }<10 \% \text {. High grade } \\
\text { with necrosis- inferior } \\
\text { outcome }\end{array}$ \\
\hline Ganglion cyst & $\begin{array}{l}\text { Joint capsule, tendon } \\
\text { sheath, ligaments, hip, } \\
\text { groin }\end{array}$ & $\begin{array}{l}\text { Asymptomatic mass, } \\
\text { vascular compression, } \\
\text { femoral thrombosis, } \\
\text { sciatica. No trauma. } \\
\text { Adults and children } \\
\text { with females>males }\end{array}$ & $\begin{array}{l}\text { Myxomatous degeneration } \\
\text { of fibrous tissue structures. } \\
\text { Synovial cell lining on cyst } \\
\text { wall is absent }\end{array}$ & $\begin{array}{l}\text { Mild possibility of } \\
\text { localized recurrence }\end{array}$ \\
\hline
\end{tabular}

The subcutaneous neoplasm enunciates the undulating fascicles of spindle-shaped tumour cells admixed within a myxoid matrix and disseminated collagen fibres. Several mitotic figures are observed along with rents and spaces within the cellular aggregates. Tumefaction is immune reactive to $\alpha$-Smooth Muscle Actin ( $\alpha$-SMA) and immune nonreactive to S100 protein, $\beta$-catenin, CD34, cytokeratin, Epithelial Membrane Antigen (EMA), caldesmon, desmin and High Mobility Group AT-hook 2( HMG-A2) [5,6]. Pigmented Villonodular Synovitis (PVNS) is a neoplasm composed of mononuclear stromal cells infiltrating the synovium, extensively vascularized villi layered with plump, hyperplastic synovial cells, an admixture of haemosiderin laden macrophages, multinucleated giant cells, pigmented foam cells
Myxoid neurofibroma is a neoplasm that may incriminate a peripheral nerve. The neoplasm is immune reactive to $\mathrm{S} 100$ protein $[5,6]$. Myxoid liposarcoma demonstrates typical "signet ring" lipoblasts admixed within an arborizing vascular pattern $[5,6]$. Low-grade fibromyxoid sarcoma displays alternating fibrous and myxoid cellular component with a swirling, whorled configuration [5,6]. Low-grade myxofibrosarcoma or myxoid malignant fibrous histiocytoma is a cellular neoplasm delineating "arched" vascular articulations along with foci of cellular and nuclear pleomorphism and moderate mitotic activity $[5,6]$. Cellular myxoma is a bland, hypocellular neoplasm which is devoid of classic, minimally cellular areas. "Arching" vascular configurations are exemplified $[5,6]$. Nodular fasciitis is a benign, reactive, posttraumatic, rapidly progressive proliferation of myofibroblastic cells (Table 1). or lipid rich histiocytes and frequent mitotic figures $[5,6]$.

Juvenile idiopathic arthritis depicts a proliferative synovitis with synovial cell hyperplasia and hypertrophy, a dense, perivascular inflammatory infiltrate of lymphocytes and plasma cells, configuration of germinal centres, enhanced vascularity with hemosiderin deposition and neutrophilic aggregates upon the synovial surface. Additionally, erosions, osteoporosis, configuration of a pannus and progressive fibrous or bony ankylosis may be denominated $[5,6]$.

Synovial osteochondromatosis is a lesion comprised of nodules of mature hyaline cartilage of variable cellularity accumulated within the synovial tissue and joint spaces. Chondrocytes depict variable atypia or binucleate configurations. Aggregates of 
chondrocytes articulate tumour lobules and incriminate the synovium. Accompanying arthritis is usually absent $[5,6]$. Lipoma arborescens is constituted by hypertrophic villous projections of mature adipose tissue layered with synovial cells and a variable intermingling of inflammatory cells $[5,6]$. Synovial haemangioma is a neoplasm composed of an admixture of distended vascular channels with cavernous or capillary vascular articulations. Haemosiderin pigment deposits are layered along the synovial lining with disseminated haemosiderin laden macrophages. Lymphoid follicles, stromal giant cells or morphologic features indicative of aggressive biological behaviour are absent $[5,6]$. Hibernoma is composed of aggregates of brown adipose tissue cells admixed with myxoid articulations. However, the neoplasm is immune reactive to $\mathrm{S} 100$ protein and CD34 [5,6]. Juxta-articular myxoma requires segregation from meniscal cysts, haemophilia or nonspecific synovitis. Additionally, pathologies of hip joint requiring distinction from juxta-articular myxoma are conditions such as slipped femoral epiphyses, osteomyelitis, leukaemia, osteoid osteoma, Ewing's tumour and osteosarcoma. Aforesaid disorders depict identical clinical findings and represent as a limp or pain in the hip joint $[6,7]$.

\section{Investigative Assay}

Plain radiography demonstrates an absence of incrimination of abutting bone. On ultrasonography, a complex tumefaction of enhancing magnitude composed of solid and cystic foci is denominated [6,7]. Magnetic Resonance Imaging (MRI) depicts an elliptical, well-encapsulated lesion of varying magnitude. The neoplasm is traversed by branched fibroconnective tissue septa and demonstrates a minimal endo-structural diffusion besides irregularities of tumour wall although tumour infiltration into surrounding tissues is absent $[7,8]$. On MRI, a wellcircumscribed, septate, minimally vascularized tumefaction with absent tumour vasculature is discerned. Preoperative magnetic resonance imaging may be nonindicative of the magnitude of the neoplasm. The resected neoplasm can be miniature or enhanced in concurrence with imaging features on account of brisk tumour progression or compression due to surrounding soft tissue with consequent underestimation of tumour dimension $[7,8]$. Total body scintigraphy delineates an absence of metabolic activity within the lesion $[7,8]$. Assessment of cogent tissue specimen can be inefficacious on account of accumulation of nonrepresentative tissue although the procedure is contemplated as an accurate methodology of tumour discernment. Adoption of a singular incisional biopsy can engender a misinterpretation $[7,8]$.

\section{Therapeutic Options}

Comprehensive surgical eradication of the neoplasm is a recommended treatment strategy on account of significant proportion of localized tumour reoccurrence(34\%). Surgical extermination of the neoplasm is recommended when ingestion of Non-Steroidal Anti Inflammatory Drugs (NSAIDs) fails to alleviate the lesion [7,8]. Marginal surgical resection with a broad, tumour free perimeter is optimal. Comprehensive surgical extermination mandate the exclusion of diverse structures such as joint ligaments, tendons, nerves or vascular articulations. Occasionally, additional surgical procedures such as meniscal resection may be necessitated $[7,8]$. On account of enhanced localized tumour reoccurrence encountered in myxoid tumours subjected to inadequate tumour extermination, an aggressive therapeutic approach and cogent postoperative monitoring is critical to discern tumour relapse or a malignant metamorphosis $[7,8]$. Appropriate follow up for a minimum period of 2 years is recommended. Tumour monitoring with regular, annual ultrasonography and MRI is beneficial $[7,8]$.

\section{Conclusion}

Juxta-articular myxoma requires a distinction from benign and malignant neoplasms such as intramuscular myxoma, myxoid neurofibroma, myxoid liposarcoma, low grade fibromyxoid sarcoma, low grade myxofibrosarcoma, cellular myxoma, nodular fasciitis, pigmented villonodular synovitis, juvenile idiopathic arthritis, synovial osteochondromatosis, lipoma arborescens, synovial haemangioma, hibernoma, meniscal cysts, haemophilia or nonspecific synovitis. Pathologies of hip joint requiring distinction from juxta-articular myxoma are slipped femoral epiphyses, osteomyelitis, leukaemia, osteoid osteoma, Ewing's tumour and osteosarcoma. On magnetic resonance imaging, a well circumscribed, septate tumefaction with absent tumour vasculature is discerned. Comprehensive surgical eradication of the neoplasm is recommended on account of significant localized tumour reoccurrence.

\section{References}

1. Virchow R. Band 1 (1863) Berlin: Verlag August Hirchwald. Die krankhaften geschwulste. pp. 369-434.

2. Raffaele A, Goruppi I, Mosconi M, et al. (2019) Juxta-articular myxoma of the hip: A rare paediatric tumour. J Am Acad Orthop Surg Glob Res Rev 3(11): pp. e070.

3. Claudi C, Andreisek G, Vrugt B, et al. (2020) A juxta-articular myxoma of the thumb. J Hand Surg Glob Online 2(3): pp. 171174.

4. Beggan C, Davies K, Leader M (2014) Juxta-articular myxoma: An unusual benign mesenchymal lesion, readily mistaken for malignancy. Ir Med J 107(7): pp. 212-213.

5. Korver RJ, Theunissen PH, van de Kreeke WT, et al. (2010) Juxta-articular myxoma of the knee in a 5 year old boy- a case report and review of the literature. Eur Radiol 20(3): pp. 764768.

6. Ozcanli H, Ozenci AM, Gurer El, et al. (2005) Juxta-articular myxoma of the wrist- a case report. J Hand Surg Am 30(1): pp. 165-167.

7. Irving A, Gywnne-Jones D, Osipov V, et al. (2012) Juxtaarticular myxoma of the palm. J Surg Case Rep 2012(6): pp. 12.

8. Okamoto S, Hisaoka M, Meis-Kindblom JM, et al. (2002) Juxtaarticular myxoma and intramuscular myxoma are two distinct entities-activating Gs mutation at Arg 201 codon does not occur in juxta-articular myxoma. Virchows Arch 440(1): pp. 12-15. 